\title{
Andrew Willet, \\ England's First Religious Emblem Writer
}

PETER M. DALY AND PAOLA VALERI-TOMASZUK

Andrew Willet (1562-1621), England's first religious emblem writer, is today little known and less often read. Yet in 1598 Francis Meres could write with evident pride in his Palladis Tamia, "As the Latines have these Emblematists, Andreas Alciatus, Reusnerus, and Sambucus; so we have these, Geffrey Whitney, Andrew Willet and Thomas Combe"'(fol. 285v). Willet's emblem book, entitled Sacrorum emblematum centuria una (Cambridge, 1592?), is today extremely rare. In his own lifetime, however, Willet was a popular author, and his Sacra emblemata would have been recognized as a work of some significance. Willet and his emblem book deserve more attention than they have received in modern scholarship. ${ }^{1}$

We here attempt to characterize the work as a whole, indicating its place in the development of the emblem genre. We concentrate on a description of the themes of its emblems, the organization of the book, and Willet's use of English and Latin. We shall reserve a consideration of Willet's use of emblem form for a later separate treatment. Suffice it to say at this point that he had a good understanding of how an emblem works; he created effective emblems, though his epigrams are not of high literary quality.

Willet was as prolific a writer as he was a father, producing at least fortytwo books (nine unpublished at the time of his death), not counting fresh editions, and eighteen children. He distinguished himself with Bible commentaries and anti-catholic writings; he was especially critical of papal claims. His major work is Synopsis Papismi: that is a generell viewe of Papistry; wherein the whole mysterie of iniquitie, and summe of Antichristian doctrine is set downe, which is maintained this day by the Synagogue of Rome, against the Church of Christ, together with an Antithesis of the true Christian faith, and an Antidotum ... (London, 1592). This volume of some 626 pages was re-issued four times up to 1635 , assuming a leading place in the literature of theological controversy of the day. Something of the stridently anti-papal tone of the Synopsis Papismi also informs Willet's sacred emblems, which appeared in the same year. One year later he published the Tetrastylon Papisticum, that is, the foure principal 
pillers of Papistrie ([London], 1593), which went through four printings and was often bound together with the Synopsis Papismi.

His extraordinary productivity might suggest that Willet was excessively bookish and that theology was his exclusive concern. Nothing could be further from the truth. In an age when religion and politics were inextricably mixed, it is only natural that he should take a lively interest in politics and government. Indeed, his preferment also depended to a degree on patronage. Thus, we are not surprised to find Willet writing a work to welcome King James to the throne, the title of which reflects the interdependence of religion and government: Ecclesia Triumphans: that is, the Ioy of the English Church for the happie Coronation of the most vertuous and pious Prince Iames. . . and for the joyfull continuance of religion and peace by the same (Cambridge, 1603). A second edition appeared in 1614. Willet frequently preached at court, was admired by King James and became chaplain-in-ordinary and tutor to Prince Henry.

Although Willet enjoyed James's favour as a preacher, the King did not take kindly to his subject's interference in matters of state and international diplomacy. Willet was opposed to the Spanish match and sent letters to Parliament through Sir John Higham of Bury urging them to protest the proposed alliance. He also sent copies of the arguments to the King who was sufficiently angered to have Willet imprisoned for a month. ${ }^{2}$

The Sacra emblemata is an early work. Although the title-page does not indicate the date of publication, Rosemary Freeman suggests from internal evidence that it could not have been written before 1591, and not after 1592. Emblem 83 is dedicated to Richard Vaughan, rector of Dunmow from February 1591 to August 1592. Willet's emblem book in fact contains many such dedications. Book dedications and dedicatory emblems of this period may be regarded as attempts on the part of the author to obtain protection and patronage. This is certainly true of Andrew Willet, who was just embarking on his career; he refers to himself in the preface as "a new poet" (A2r).

By virtue of his Sacra emblemata Willet may be regarded as the first writer of an original emblem book in the English language. Geffrey Whitney's $A$ Choice of Emblemes and Other Devises (Leiden, 1586) predates Willet's emblem book but is largely a translation or adaptation of continental emblems from Alciati, Sambucus, Paradin and others. Jan van der Noot's Theatre for voluptuous Worldlings (London, 1569) and Samuel Daniel's The Worthy Tract of Paulus Iovius (London, 1585) are likewise translations.

Willet's work does not belong to the mainstream of sixteenth-century emblem books. Its religious matter sets it into a trend that developed out of the earlier secular tradition. Whereas Alciati and subsequent humanist emblem writers occasionally devoted a few emblems to religious or 
theological themes, the first proper religious emblem book was written by the Huguenot Georgette de Montenay (1540-1571). Her Emblemes, ou Devises Chrestiennes were printed in Lyons in the year 1571. It is perhaps a little surprising that it should have taken so long for someone to recognize the potential of the emblem form for religious instruction and spiritual edification. Indeed, forty years had elapsed between the publication of Alciati's Emblematum liber (Augsburg, 1531) and the appearance of de Montenay's Emblemes. The Jesuits were even slower than the protestants in appropriating the new form, but having discovered the emblem they soon exploited it, producing over 400 titles $^{3}$ during the next two centuries following the appearance of their first emblem book, Hermann Hugo's Pia desideria (published in 1624). It is then between Georgette de Montenay and Hermann Hugo that we must place the emblems of Andrew Willet. Willet does not, however, seem to have known consciously the work of de Montenay. Although Whitney had incorporated ten of her emblems in his collection, he did so without attribution. ${ }^{4}$ Even though Willet knew Whitney's $A$ Choice of Emblemes, he would not have known this source.

\section{$* * *$}

Let us begin with Willet's title-page, which sets out the purposes and organization of the Sacrorum emblematum centuria una. The following is a close translation:

\section{ONE HUNDRED \\ SACRED \\ EMBLEMS}

which are as aptly expressed to point an example and as beautifully depicted ${ }^{5}$ as those, which, handed down by the ancients or composed by others, are still extant.

They have been divided into three classes of which the first contains Typical or Allegorical Emblems: the second historical ones or recorded events ${ }^{6}$ : the third Physical Emblems drawn from nature.

All derived from the purest sources of the Scriptures and rendered into Anglo-Latin verses.

Although the title-page announces that the work is written in English and Latin, only the epigrams appear in both languages. The title-page, the preface, all the dedications and quotations, and all one hundred mottoes are in Latin only. The English translations have the appearance of an afterthought, if the clumsiness of the English is any indication. This is a subject we shall return to. Interestingly, Willet's first book De animae natura et 
viribus quaestiones quaedam (Cambridge, 1585), a treatise in prose, was likewise written in both Latin and English, although the title is in Latin. In the Sacra emblemata, despite the English, Willet's primary intended audience is clearly an educated readership, as is apparent from the references to his alma mater, Cambridge, and to his friends and teachers at that university.

To this audience, Willet addressed his lengthy Latin preface, which we quote in its entirety in English translation in an appendix. In it he praises his patron and outlines his work. He also touches on a sensitive matter-the lack of illustrations to his work. Despite his regret, however, it was far from unusual for an emblem book to have no pictures. Heckscher and Wirth estimate that as many as a tenth of all emblem books were unillustrated. ${ }^{7}$ In his preface Willet sets out the reasons for the omission of pictures, and what he says reflects the conditions of book production in England at the time. The first reason is financial: the cost of adding "forms and figures" (A3r) to the text "would weigh me down with expense" (A3r). This is a complaint often heard. ${ }^{8}$ Even when illustrated, many emblem books are incomplete as far as plates or woodcuts are concerned. To take but one example, in Jeremias Held's translation of Alciati's emblems (Frankfurt a. Main: S. Feyerabend, 1567) no less than 85 of the 212 emblems are unillustrated. Willet also observes that "engraving of that kind . . . does not well suit my press, and is awkward because elaborate ..." (A3r). Emblem books do present problems of layout. Printers often got the plates out of sequence, even repeated the same plate twice, again as in the Held translation. ${ }^{9}$ Finally, Willet informs us that the production of engraved "forms and figures" is also "too unfamiliar since it lacks a model" (A3r). In a sense Willet is right. By 1590 no emblem book with woodblocks or plates engraved in England had been pubished, and thus there was no local model or native tradition to refer to. Yet Englishmen were aware of continental developments; afterall, Whitney had published a substantial volume of emblems on the continent. And there were models, at least in the form of those engraved "comely frontispieces," often richly symbolic in character, employed by certain English authors and publishers. ${ }^{10}$

Willet's collection contains 100 emblems, beginning with a dedicatory group of five and the rest divided into three sections. The dedicatory emblems are hierarchically arranged and addressed to Elizabeth I (no. 1), the Earl of Essex (no. 2), Lady Walsingham (no. 3) (accompanied by lengthy poems on the death of her husband, Sir Francis Walsingham), the Duke of Rutland (no. 4), and finally the Duke of Bedford (no. 5). As one would expect from Elizabethan dedications, the praise is full and elaborate.

While the dedicatory emblems combine the conventional gesture of obeisance to the powerful with the implied request for patronage-patronage 
is one of the important matters dwelt upon in Willet's preface - these emblems also deal with matters that remained of importance to Willet as a patriot, churchman and father. Willet, like Whitney earlier, addresses his first emblem to Queen Elizabeth as protector of the nation. The "good prince" who protects his people is exemplified in the shade-giving tree. Willet adds to this emblem a Latin pattern poem in the shape of a tree. The Queen is described in religious terms as a "blessed virgin ... milk to the nations"; she is likened to a "plane tree: when a heavy storm suddenly breaks, birds hide in its leaves and animals come to lie under it"; Elizabeth is also "the pillar of our homeland." Whitney had used the emblem of a pillar supporting ivy in praise of the Queen.

Emblem 2 exhorts the moral and spiritual life expressed through the motif of the deer, which was the heraldic animal of the Essex family. The pattern poem, complicated by the use of versus rapportati ${ }^{11}$ in the closing lines, reads:

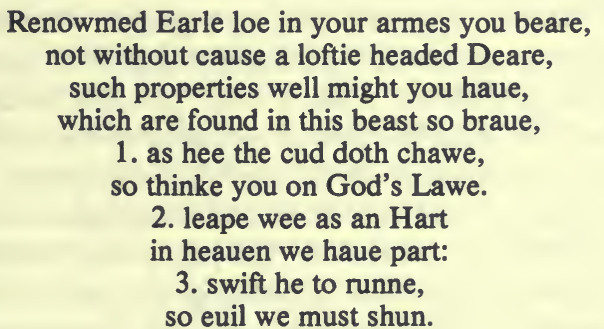

4. for water he doth lust, for faith wee labour must.

euen so then these fowre are all:

1. good thinges oft to minde to call

2. to joy in spirite, 3. to be patient,

4. for faith to thirst which is neuer spent:

to 1 . meditate, 2 . beare, 3 . seeke, 4 . enioy, these fower

1. things holy, 2. euill, 3. good, 4. hope, to blesse haue power.

Andrew Willet interprets emblematically the stag as signifying meditation, patience, the avoidance of evil, and faith, which four qualities, deriving from the "properties" (1.3) of the stag, the Earl of Essex is said to possess.

In the third dedicatory emblem Walsingham is celebrated in a long poem, in a series of short "sentences" uttered by his wife, daughters, sisters and friends, and finally by a lengthy dialogue between Church and Country, all vying with one another in expressing sorrow at his death and praising his accomplishments. The emblem offers consolation in death by reference to Ezekiel, and belongs to the ars moriendi tradition, a subject of considerable interest to an ordained minister. 
Emblems 4 and 5 are dedicated to the Dukes of Rutland and Bedford, who, we are told, are "most noble youths ... leading a studious life at the University of Cambridge" (B4v). They are praised by reference to both the lore of angels and the application of the religious imagery of the tetramorphs. The emblems praise the youths as the joy of their families (no.4), and exhort them to virtue and studiousness (no. 5).

The three main groupings of emblems are named on the title-page as "Typical or Allegorical," comprising numbers 6-37, "recorded events" emblems 38-76, and "Physical, drawn from nature" (nos 77-100). In this classification Willet might seem to follow Whitney's lead, although the latter does not in fact organize his emblems into three divisions, nor does he actually name the classification on his title-page, as Willet suggests (Preface A2r). None the less, Whitney does discuss "Historicall, Naturall, \& Morall" emblems in his preface "To the Reader" (**2r). Most emblem books, including Whitney's $A$ Choice of Emblemes, are not thematically organized. They are collections of self-contained verbal-visual statements, which the author makes little attempt to organize into logical groupings. Willet was, therefore, unusual in imposing a degree of order and organization on his book of emblems. This is seen not just in the division of his emblems into three sections but also in occasional thematic sub-groupings.

Willet's section of typical or allegorical emblems begins, fittingly enough, with a group of four emblems dedicated generally to the church. Emblem 6 treats of bishops, emblem 7 the pious laity, emblem 8 the church as pillar of truth whose ministers dispense grace, and emblem 9 broadens the focus to embrace the church as the home of all nations. Emblem 8 may serve as an example of this group:

The Prophet espieth a golden candlesticke,

Seauen burning lamps shine in the top thereof,

So many pipes there are, which oyle minister,

Two oliue trees, which vpon each side doe stand,

The Prophet seeth, they giue oyle abundantlie.

The Church and house of Christ is this candlesticke,

The lampes doe shew forth Gods graces manifolde,

The pipes which runne oyle signifie ministers,

This oyle the spirit is, Christ is the oliue tree.

Alwaies at their neede, he readie is at hand,

As running spring his Prophets he cherisheth.

The next major grouping deals generally with man's lot in which joy follows suffering (no. 11), and affliction is justified as working for man's good, as demonstrated by the images of plowing and sowing (no.12). If this emblem implies divine will, then emblems 14 and 15 make explicit the role of divine providence. The motif of Jacob's ladder exemplifies God's guiding of man, whereas Jacob's struggle with the angel signifies that God 
afflicts man to prevent pride. Willet then moves from the positive to the negative in emblem 16 where he deals with unstable lot of the wicked who experience sorrow after a time of ease, which is exemplified by the grasshopper (no. 16); this in turn is followed by the punishment of the ungrateful with grief (no. 17).

Willet returns to the general subject ${ }^{12}$ of the church in a group of three emblems. Number 18 treats of the church of Christ and the role of baptism, faith and grace through a point by point comparison with Noah's Ark. This positive emblem is then balanced by the following emblem (no. 19) denouncing the Catholic church as the false church. The emblem is one of the few that has an English dedication: "To the English Papists." The full Latin dedication reads in our translation: "Against all the evil and obstinate patrons, promoters or servants of either the Roman pontifical superstition or its anti-christian power." The motif that embodies this theme is that of the pot consumed by the fire, meaning the wicked, i.e. the Roman Catholic church, is destroyed by "God's wrath" (no. 19). In true Protestant tradition the next emblem picks up the theme of the gospel, God's word, together with its "faithful preachers" (no. 20).

The other emblems in this first section show no particular grouping or organization. They deal with the church (nos. 18, 20), Catholicism (nos. 19 and 22, which is virulently anti-papal), the gospel and preachers (nos. $20,24,25,32,35)$, God's judgement and the punishment of the wicked (nos 21, 27), the need to be generous to the poor (no. 26), the breaking of oaths (no. 24), the value of silence for young students (no. 31), the dangers of an evil tongue (nos. 33 and 34), and the vanity of greed(no. 36). There is an odd emblem that simply names the four great empires of Syria, Persia, Greece and Rome (no. 30) by reference to the symbolic animals seen by Daniel in his vision (Daniel chapter 7).

Willet's second group of emblems carries the title "historical emblems or recorded events." The events are associated for the most part with specific personages in the Old Testament who have a typical, or almost paradigmatic value. The person or event becomes the bearer of meaning which is interpreted morally or spiritually. In his preface Willet describes this section of emblems as "representing real events described by historians." The events derive from the Old Testament, the books of which were regarded as both the histories of the Jewish people and the word of God. No less than 27 of the 38 emblems are dedicated to events associated with individuals in the Old Testament. These include Moses and the burning bush (no. 42), the rivalry of Jacob and Esau (nos 44 and 75), Eli fed by ravens (no. 46), Uzzah and the ark (no. 48), allusions to David and Bathsheba (no. 50), Hezekiah's destruction of Moses's brass serpent (no. 51), the killing of Nadab and Abihu (no. 52), Adoni-Bezek (no. 55), Joab (no. 57), Jesabel (no. 58), and Dagon(no. 61), Jonah and the whale (no. 53), 
David (no. 56), the martyrdom of the seven Maccabees (no. 59), the walls of Jericho (no. 60), Adam, Eve and the serpent (no. 64), Moses's tables of the law (no. 72), and the Isrealites (nos. 73 and 74). These are then interpreted morally or spiritually. Thus the feeding of Eli in the wilderness by ravens signifies divine providence for those who trust, and David's lusting after Bathsheba is a moral warning that sloth causes unlawful passion. In one instance, an Old Testament figure is interpreted christologically. Melchisedech, the priest and king, pre-figures Christ (no. 63):

\footnotetext{
Bread and wine to Abraham bring

Melchisedech doth both priest and king:

Hee blesseth him with speach full graue,

The other tithes vnto him gaue:

Of noble stock this prohet came

To Noah sonne, Sem is his name,

A type of Christ, his precious blood,

And flesh for bread must be our foode:

Of righteousnes and peace they call

Him king, which fitly on Christ fall,

For he shall iudge the world most iust,

On him for peace depend we must.
}

The subjects of these emblems represent a broad spectrum of unrelated themes. They range from the hope for reconciliation of the Jews with Christianity (no. 38), through the virtues of housewifery (no. 39), the majesty of princes (no. 49), God's wrath and punishment (no. 54), laziness (no. 65), the education of children (no. 67), the tables of the law (no. 72), and old age (nos. 70 and 71 ) to the notion of reward for labour (no. 76). No pattern emerges.

Willet's final section of "physical emblems drawn from nature" is the most unified group in their motifs, but reveals no thematic organization. The section begins with an emblem on the efficacy of God's word (no. 77), which is followed by an emblem on sin, a subject taken up again in emblems 85 and 100. Related to this are the themes of wickedness (no.93), religious hypocrisy (no. 94) the fall of righteous men (no. 81), and the evil of Catholic heresy (no. 38). A small scattered group deals with the constancy of God (no. 80) and the power of God (nos. 89 and 90), while emblem 92 deals with divine protection. A pair of emblems focus on kingship, with number 95 stressing the power of the king to punish evil, and number 96 dealing generally with the dignity of kingship. Two other emblems take up the theme of the wisdom of animals as a lesson to man (nos. 82 and 97).

Nature may be God's second book, but Willet frequently chooses his nature motifs because of their Biblical significance. Thus emblem 91 dealing with man's desire for Christ has as its central motif the eagle with special reference to Matthew 24.28: "For wheresoever the carcase is, there 
will the eagles be gathered together." In interpreting his nature motifs, Willet shows that he is quite conscious of the exegetical tradition within which he works. The qualities and actions of the creatures he names are clearly regarded as bodying forth significance. It is therefore no coincidence that Willet uses the word "properties" on at least two occasions when interpreting, or allegorizing, a nature motif. In emblem 94 we encounter the viper as a symbol for the hypocrite for three specific reasons:

The viper after deadly bite, the water doth desire,

Who outwardly is faire to sight, but burn'th within as fire:

When damme the viper hath brought foorth, shee is depriued of life,

These two qualities and one action are named by Willet "properties," which apply to hypocrites. In the second half of the epigram he applies these properties, or one might say, he interprets these aspects of the viper, point by point:

For as to water they doe runne, things holy to pertake, And baptisme too, yet what is done, doth nothing for them make:

Without a goodly shew is made, yet euill they are in hart,

And they which teach the heauenly trade, of their tongues feele the smart.

Curiously enough Willet fails to interpret the third "property" of the viper, which he describes (1.3), namely that the female dies at the birth of her young. The common belief was that the young bite their way through the mother's belly at birth thereby killing her.

The things and creatures of nature may be interpreted positively, in bonam partem, or negatively, in malam partem. The viper is one of the many instances of interpretation in malam partem. ${ }^{13}$ Other examples are the wood of the barren vine, which is good only for burning (no. 81), the destruction caused by locusts (no. 83), the reckless horse and rider, connoting $\sin ($ no. 85), the bitter mulberry in its arid valley (no. 86), the ostrich which abandons its eggs to the sand, exemplifying the improvident mother (no. 88), the dog barking at night (no. 93), and finally the leopard which cannot change its spots, indicating indelible sin (no. 100).

Occasionally Willet will interpret his nature motif both positively and negatively. Wormwood may have a "good colour" but its taste is "sault as fire." This is used to teach the truth that evil is "poysonfull within" and yet "In shew both faire and smoth" (no. 78):

What herb this is leaue to enquire

They wormewood doe it call,

Of colour good, but sault as fire,

The taste shall be with all.

So euill is poysonfull within, 
In shew both faire and smoth,

But righteous men the worke of sinne

as bitter hearbs doe loth:

O happie thou vnto whose heart

Vice hath a bitter tast and tart.

For the rest, however, the nature motifs are interpreted in bonam partem. Thus the mustard seed, which grows quickly to a "tree" signifies that truth and faith will prevail (no. 79). The oak and cedar stand for the constancy of God and of righteous men (no. 80). The behaviour of the crane and ox teaches us not to forget the name of God (no. 82). The unity and industry of bees instruct man that peace and prosperity are achieved through unity of effort (no. 84). The elephant, the whale and the eagle are emblems of the power of God manifest in creation (no. 89, 90 and 91). The wind that sifts the chaff and the lion that frightens the sheep embody the idea that the king has the power to punish evil (no. 95). The grasshopper, ant, rabbit and spider can all teach man lessons of wisdom (no. 97).

*** *

Willet's Sacra emblemata is an avowedly religious work, but it is not without a certain political message. Political and social attitudes may be expressed directly or indirectly. Silence can be as eloquent as speech - what a writer leaves unsaid may be almost as significant as what he says.

The most obviously political emblems are those that deal with kingship and the exercise of power. A number of emblems may be regarded as belonging to the tradition of the mirror of the prince. Emblem 1, dedicated to Queen Elizabeth, praises the good prince, or in the words of the motto "Encomium of the good prince." What the shade-giving tree is to the birds and beasts, the king is to his people:

Such is a King, that carefull is, who doth his bring all ioy and blis:

By way of contrast emblem 10 is concerned with the bad prince who is careless. Just as a baker through laziness or sloth may burn his bread,

So is it when the Prince doth cease,

For countrey to prouide,

The publike weale doth soone decrease

And all things go aside.

The power and majesty of the institution of monarchy is celebrated in emblems 49, 95 and 96. King Solomon's magnificent throne of ivory, 
decorated with gold, precious stones, and twelve carved lions is, for Willet, a veritable symbol of kingship:

We learne what is for Princes meet.

They fearfull euen as Lyons be,

Glittering with gold and Iuorie

Worship belongeth to their sea.

The motto is appropriately enough "The majesty of the prince." The institution of monarchy is both magnificent and commands "fear." Emblem 96 deals with the "dignity of the king," as the motto puts it. This dignity is expressed visually by means of the comparison with the greyhound, goat and lion, all of which are said to have "a comely gate." Interestingly enough, the two-line interpretation goes beyond the idea of dignity in order to stress the duty of people to "honour" the king and "not to impayre his state," that is, not to limit his power. This complete acceptance of the power of the king is made explicit in emblem 95. The motto reads "The authority of the king" and this is followed by a quotation from Ecclesiastes 8,4 indicating that no-one has the power to question the actions of the king: "Where the word of a king is, there is power: and who may say unto him, What doest thou?" The emblem is, however, concerned with the power of the king to punish evil and vice. Just as the wind "doth sift both corne and cloud" and as the lion frightens sheep, so

In the kings sight vice can not shroude.

But as chaffe, cloud, sheepe flieth away:

Acceptance of the authority of the ruler becomes the subject of emblem 54 . The motto "The duty to princes" and the epigram make it abundantly clear that it is the duty of all men to obey the authority of home, church and state as vested in the father, the pastor and the prince. These representatives of authority may well have "faults" but that should in no way detract from the obligation of obedience:

\footnotetext{
Euen so their faults wee must passe by,

In parents stead which vs doe lye,

Prince, father, pastour to belye wee must detest.
}

Obedience to authority is evidently still required when the ruler is a tyrant. One of the themes of emblem 33 is that God ultimately has control over the "rage" and tyranny of men. The implied picture features both a Nemesis figure holding a bridle and a rider controlling his horse by the bit. The interpretation follows immediately: 
Euen so mens rage God soone doth stay, and tyrants alwayes beare not sway, God will not suffer them to stray

beyond limits set.

The explicit statement is that God in his foreknowledge and providence regulates all things. The implication is that it is given to the subject to bear patiently bad government and an evil king.

If obedience is the duty of the subject, and criticism of the king's actions denied, how much less would it be possible to seek to redress the evils emanating from the king? Some emblems have significant political implications, but they are not exploited. For instance, emblem 55 deals with the just punishment God meets out to evil men generally, but the example taken is the punishment of the blood-thirsty and tyrannical king AdoniBezek as set out in Judges 1 . Willet deals less with the tyranny of this king than with God's just punishment of him. The implication is inescapable: it is for God to punish and not man. There is no room in Willet's world-view for political rebellion. He evidently subscribes to the Tudor monarchist ideology, which sees in the person of the king God's vice regent and vicegerent on earth - that is, the theory of the divine right of kings.

Willet's loyalty to his sovereign was apparently unlimited. In the preface he observes that the work is dedicated to "Her Royal Majesty" and he adds "to whom we owe not only our studies but our life and soul" (A3v). Although Willet was a monarchist, far removed from Puritanism in his social and political outlook, he was still not above questioning, indeed criticizing, certain political policies of his day. As was stated earlier, Willet opposed the Spanish match during the reign of James. He went so far as to send a copy of his arguments to James himself, which action resulted in his temporary imprisonment in February 1618.

The Sacra emblemata, like some other early emblem books in vernacular languages, has both Latin and vernacular texts. ${ }^{14}$ In Rosemary Freeman's view, Willet's Latin is "more accomplished"15 than his English verse; in fact his Latin has a self-confident fluency that approaches spontaneity. His knowledge of classical versification is outstanding. He passes from sapphics to hendecasyllabics to elegiac couplets and then to combinations of his own invention. This reminds one of the extraordinary variety of metres in Boethius's widely read De consolatione Philosophiae, which, as it happens, Elizabeth translated into English in the year 1583. ${ }^{16}$

Although technically superior, Willet is not an outstanding poet. Even so we cannot begrudge him that slender vein of poetry which appears here in certain felicitous Latin phrases. One would expect his own English versions to show the same linguistic competence, some knowledge of metres and quasi-poetic utterance. But this is not so. Rosemary Freeman commented 
early on the "feebleness" (p. 54) of his English verses, which have a "home-made air" (p. 64) about them. In her introduction to the edition published by Scholars' Facsimiles \& Reprints in 1984 Betty Anne Doebler finds the English poems to be "aesthetically ... disappointing" (p. iii), quoting emblem 14 as an example. But this emblem is not typical of Willet's worst verse. The fact is Willet's English is extraordinarily clumsy. The rhyme takes precedence over all - no matter how unsuitable the words chosen, how awkward the syntax, or how distorted the logical order. Moreover, as a translation of the Latin, the verses frequently omit key images while repeating other details.

The inconsistency between the Latin and the English is particularly evident in a group of emblems where the emotional tension combined with a suitable metre create the nearest thing to poetry in Willet's work. They are emblems 54, 60, 71, 74 and 87.

Emblem 54, in sapphics, is a poem of impeccable style. In it we find Willet's personal interpretation of the Biblical story of Noah and the reaction of his sons to their father's drunken nudity.

Officium in principes

Emblema. 54.

Hic iacet nudus requiem Noachus

Ebrius carpens: sceleratus illum

Vidit irridens Chamus indicatque

Fratribus istud.

Sem Iaphet sumpta properant retrorsum

Et decenter veste tegunt parentem

Non patrem cordi est aliis inermem

E gravi somno pater excitatus, prodere natis

Conscius, nati sibi, quid patrassent, Increpat Chamum, reliquos paterno Ore beavit

Nuditas nobis ita contegenda est

Omnium semper, vice qui parentum,

Non magistratus, patris, aut ministri

Crimina fanda.

Here Noah naked lieth at rest

Hauing well drunke, but Cham doth iest

His wicked sonne, and yet thinkes best

Sem, Iaphet do a garment take to tell his brethren.

To couer him, turning their backe,

They ioyed not their father to make A scorne to men.

Their father knowing now awake,

What his children had done for his sake, 
To cursed life Cham he doth betake.

The other are blest.

Euen to their faults we must passe by,

In parents stead which vs doe lye,

Prince, father, pastour to belye

wee must detest.

Increpare (to scold and not to curse) is used in 1.11 with reference to Cham. The translation, however, adheres to the Biblical Maledictus Canaan in: "To cursed life Cham he doth betake." The word order in lines 6-7 is remarkable:

\section{Sem Iaphet sumpta properant retrorsum \\ Et decenter veste tegunt parentem}

Shem and Japheth snatching a cloak, back up

Hurriedly and properly cover their father [our translation]

The position of sumpta and veste, encasing, as it were, properant retrorsum (they back up hurriedly), makes the two actions simultaneous, i.e. Sem and Japheth turn their backs and, at the very same time, pick up a cover to cloak their father's nudity. This feeling of haste is lost in the translation where the only concern is to achieve a rhyme between take, backe and make. Indeed, to leave nuditas (1.14) of fathers and father figures uncovered, Willet explains, is a crimen (1.17). This striking equation disappears in a bland "Euen so their faults wee must passe by." The metre of the English is sapphic only in the adonics, i.e. the fourth lines. ${ }^{17}$

Emblem 60 deals with the destruction of the walls of Jericho.

\section{Non vi sed virtute, non armis sed arte paritur victoria Emblema. 60.}

En humeris arcam portant, murosque, Levitae Circu[m]dant, inflant plenius ore tubas Incessu lento, simul et clangore tubarum, Non vi sed subito moenia sponte ruunt,

Principibus sic bella pia sunt mente gerenda, Buccina sic verbi castra sonora decet

Milite non semper paritur victoria, causae Proelia sed bonitas saeva magistra regit.

The Leuites beare the walles about

The Arke, the trumpe they sound

As they goe, and with trumpets shout

The walles doe fall to ground:

So princes must warres take in hand

With good and godly mynde, 
All is not got by souldiers band

The cause th'euent doth bynd.

From a song of victory, such as this, one would have expected hexameters. Willet's unusual choice of elegiac couplets is, however, quite successful: the two long syllables that divide the line of the pentameter, the two "sobs," as Sanford calls them ${ }^{18}$ of the pentameter, instead of toning down the majesty of the hexameter, become trumpet blasts which add vigour to the triumphal march. This is more than a mere technical achievement. However, Willet's rendering "The Leuites beare the walles about/The Arke" is clumsy even if one regards the phrase "the walles about" as a prepositional object lacking the appropriate punctuation. The Latin is clear: "En humeris arcam portant, murosque Levitae/Circumdant" (Lo, the Levites bear the ark on their shoulders around the walls).

The failure to translate 1.4 "Non vi sed subito moenia sponte ruunt" (not by force but by their own will) is inexcusable. The fact that the walls fall of their own accord is, after all, the main point of the poem and it leads to the final idea that bonitas causae, the goodness of the cause, determines the outcome of battles. The metre of the English is iambic.

God's beneficence to the righteous is the subject of Emblem 71.

Contrahit ecce su[a]m gnomon retrogradus umbram, Sic Domino retro mandante senecta recurrit,

Et geminantur ei, qui recte vixerit, anni:

Atque, die subito, quasi cum sol occidat alto,

Iniusti brevior sic ci[r]cumciditur aetas.

As diall pegge once turned backe

So olde age is in comming slacke.

To righteous, yeares, when God doth bid

Are doubled, but as Sunne is hid

Euen at none dayes, and then might fall,

So wicked men not long liue shall.

Willet uses the motif of the sun and sundial to express the idea of God's beneficence to the righteous: "Contrahit ecce su[a]m gnomon retrogradus umbram" (Lo, the sun dial pin, turning back, shortens its shadow). But Willet's translation, "As dial pegge once turned backe," not only turns the image into a pedestrian simile, but omits the truly poetical point of the Latin, the idea of the shadow shrinking at noon.

The last two hexameters reflect the Scriptures (2. King, 20; Amos, 8-9) but are more vivid and plastic in their brevity:

Atque die subito, quasi cum sol occidat alto,

Iniusti brevior sic ci[r]cumciditur aetas. 
And suddenly, as if the sun were to fall at midday, the life of the wicked is thus shortened and cut off. [our translation]

Willet's English version culminates in a grotesque final line.

Euen at none dayes, and then might fall

but as Sunne is hid

So wicked men not long liue shall.

Willet's obsession with rhyme and Latin versification leads him to invert English word order and thus to create the effect of a parody.

The Latin poems, which are far superior to Willet's English verse, have a common characteristic. They share a certain level of sophistication, technical "bravura" and, especially, they create poetic effects. Yet, in all of them the most poetic phrases have not been translated or, when an attempt has been made, the result is not even a translucency, to use Eliot's phrase. It is not easy to reproduce in one's own language the exact sense and the poetic qualities of the original. When there is a marked inconsistency, however, one might assume that the author of the original and translator are two different persons. This is not so in Willet's case. For Willet, the task of recreating poetically in his own language the images he himself had created in Latin, for him a second language, should not have been impossible. At worst he could have compromised and offered substitutes for the originals. But that he should have omitted them is difficult to understand.

Even though the omissions, mistranslations, and the poor style and superficiality might create the impression that the translation is not Willet's work, but another's whose knowledge of Latin, competence in versification and poetical skill are far inferior to Willet's, yet clearly this is not the explanation. The reasons must be sought elsewhere: English education paid more attention to the classics than to vernacular literature. Willet only reflects his culture. He probably admired Latin verse more than he did English poetry; he certainly had a greater understanding of the meters and verse forms of Latin poetry. Not that classical training is necessarily inimical to vernacular verse, as we can see in the case of George Herbert, who was an accomplished Latinist and who was elected fellow and later orator at Trinity College, Cambridge. It is painfully evident that Willet tried to imitate Latin forms, failing to recognise that English, unlike Latin, is a language in which vowel length and word stress determine the accentuation of verse, i.e. they must coincide with the stressed and unstressed syllables of the verse, if poetry is to have a natural rhythm. When in 1595 Sir Philip Sidney drew attention to this in his An Apologie for Poetrie he was merely recording what good poets had practised at least since Wyatt's time. Sidney wrote "Now, of versifying there are two sorts, the one the Auncient, the other Moderne: the Ancient marked the quanititie of each 
silable... . Nowe, for rhyme, though wee doe not obserue quantity, yet wee obserue the accent very precisely: which other languages eyther cannot doe or will not doe so absolutely." 19

It is also plausible to regard the English translations as hurriedly produced additional texts to augment a work that was originally intended to be solely in Latin. The individual Latin emblems were written, as Willet informs us in his preface, in his leisure hours "while resting from more serious studies" (A2v). The English is so clumsy, the word order frequently so unnatural - the exigencies of rhyme force the pedestrian poet to do violence to the English language - that the English version may well have been an afterthought.

Seen in the context of Willet's writings, which were voluminous and almost entirely theological, the Sacra emblemata is both an early work and a peripheral, even a marginal one. But that is not unusual. For Andrea Alciati, the great jurist and teacher, and for Joannes Sambucus, the historiographer, physician, and counsellor at the Court of Vienna, the writing of emblems was likewise a secondary concern, a creative activity, which they reserved for some of their leisure hours. The interesting thing is that in each case an important and serious man devotes some of his time to the creation of emblems, using this symbolic and pictorial mode for the transmission of his thoughts. This is what the ancients called the composition of nugae, a kind of leisurely activity where the tension involved in "serious" work is lowered. Through this, one can often catch a clearer glimpse of the man, his views on the world about him, on religion, morality and questions of aesthetics. The modern student of Renaissance art, emblematics, literature and culture recognizes that the emblem was an important cultural phenomenon, a mode of symbolic communication that permeated virtually all of the verbal and visual arts. So far as the history of English literature is concerned, emblems were more significant than even Rosemary Freeman's important monograph suggests, and in the reception of emblems in England, Andrew Willet, the Elizabethan divine, played a role which deserves more recognition.

\section{McGill University}

\section{Appendlx: Willet's Preface in English Translation}

To the most illustrious lord, the earl of Essex, noble man of letters, the Maecenas of all scholars and most excellent patron, eminent for the renown of his family and even more for the glory of his own virtue, A.W., after praying for his true health of body and mind dedicates and consecrates this new poetic work.

Most learned Earl, there appeared not so long ago a booklet ${ }^{20}$ with a dedication and title similar to mine, and bearing also a classification of emblems on the front page, yet of different length and slightly dissimilar in content and method. The author thought it sufficient to have been able to transcribe accurately emblems acquired from other sources or, inspired by his own power of observation, to add appropriate new ones or to take care also to have them represented pictorially. 
As for me, in order to avoid, as it were, doing what had already been done or setting my sickle at somebody else's harvest ${ }^{21}$, merely stretching a finger to the holy spring and dipping my foot in it, I tried to find out whether I could please my readers employing the same genre but following a different path. He chose to speak in the vulgar tongue, I employed both Latin and our language. He wished his Muse to serve and honour the most noble earl ${ }^{22}$ who now has ended his life and left the world. I, most illustrious earl, in whose name this poetic work of mine appears, find no one except your honoured self equally suitable and worthy of receiving it. But what is such an insignificant tribute compared to your immense dignity, a tribute which is not worthy of you who deserve a far more distinguished homage. Therefore you, most kind sir, appear to me as the most suitable patron of a new poetic work and of a new poet. For, on one hand, your noble family which has a great number of coats-of-arms, insignia and also some emblems, claims it; on the other, your flourishing young age which is at times captivated by skillful allegorical sketches, demands it; finally, I am influenced by the consideration of your life which is truly princely, a good part of it being spent in studies of this kind. Your busy life which sometimes requires relaxation and some recreation needs this: for I hope that, when read and pondered, my words may breathe and be redolent of a certain amount of salt and wit. They were first written and dictated by me while resting from more serious studies and fell from my lips not without pleasure and a certain mental relief.

I remember, illustrious earl, and my mind is eager to recollect the time when you, having spent several years in Cambridge, deigned by your honourable presence to bestow lustre and dignity on our university. It pleases me to remember with how much zeal I, an obscure little man, burned with eagerness to add glory to your renown: I am ashamed to say it - yet I cannot refrain from speaking - but some time ago a certain philosophical essay, rough and unpolished which was itself afraid of the daylight and even ashamed to reveal its author, came into your hands. Perhaps it will not be burdensome to your kindness to turn your eyes for a moment and look into this past action: that work was mine, furtively placed in your hands, sent out by me and travelling under my orders: I instructed it not to reveal, if questioned, anything about its author. That fetus of mine, abortive indeed, is now gone and has perished and I did not seek my lost offspring lest, if found or requested it should cause shame to its parent and lest I should harm your renown then waxing and stand in its way with my excessive and inopportune zeal while more mature reflection and more accurate study might have been able, if not to promote it, at least to hinder it to a very small degree. That was the infancy of my studies, such were the first fruits of my toil. That work, because it seemed to stammer, when published caught fire and died aware of its own weakness. Those fruits, because tasteless and quite unripe, were afraid to offend anyone by their own crudity. Now, gathering my strength again, fortified somewhat by the addition of a few years, I shall return to this study, the desire to do honour to you grows anew and sprouts forth in my spirit again. So, just as my spirit has grown warm little by little and has caught fire, the flame will not soon die; nor will it be extinguished like a flame flaring up suddenly and choked at once, but as a fire now crackling later rises on high, so this ardour now hot inside me, someday will break forth into a light and your fame which in this work will begin only to glisten darkly and sparkle, will shine more brightly in later works when this fire, if it please God, will have long been nourished within my spirit.

Meanwhile accept, I beg you, this trivial little gift - such an act is typical of your kindness; I beg you to consider the spirit of the writer and the giver, not the value of the book or of the gift - this will be characteristic of your wisdom; I pray you to allow my verses, either read aloud or silently, to flow smoothly and steal into your ears or eyes - this will be a sign that you are a noble man of letters, finally take them under your patronage and welcome them kindly - this, I believe, befits your noble birth. If your dignity now wishes to know about the method adopted in this work, I shall tell you in a few words. These emblems which I decided should be one hundred in number, have been all collected and transferred here from the Holy Scripture, lest that holy and celestial field should seem to be sterile and actually unable to bear the crop which is gathered for pleasure. For, as in our fields not only grain grows which after thrashing and grinding is then made into bread suitable for the sustenance of man, but also grapes are grown whose fruit has the power and ability to gladden the heart, so from the divine meadows the pastures not only can the soul reap its own food but gains also that by which it may restore and refresh itself. It would have been appropriate to have forms and figures drawn for each emblem but engraving of that kind would weigh me down with expense, furthermore it does not well suit my press, and is awkward because it requires a great deal of work too unfamiliar since it lacks a model.

I divided the whole work into three classes: the first has allegorical emblems, the second emblems representing real events in the historical sense, the third embraces all matters connected with nature. Outside these categories, I placed three emblems at the beginning: one addressed to Her Royal 
Majesty: for to her the first and principal part of my work very justly must belong to whom we owe not only our studies but our life and soul: the second, your dignity claims as its own: for I could not bypass and fail to greet your honourable person into whose custody this offspring of mind has been handed over and entrusted. I inserted the third for a different reason which I wish to God had not existed: in fact it has a funeral hymn on the death of a most blessed man, ${ }^{23}$ who recently passed aw ay from this life, in which our country expresses its grief, which is his due, in losing a most loyal man and I, along with a host of scholars have wept sincere tears, since we will miss a most kind patron. There is one further point which I fear your kindly nature may not welcome: for I wrote on these pages, yet not many, the names of certain friends to whom also I had addressed some poems: I confess to have done this boldly, but I hope that your kindness will easily be able to forgive me. It is as if many guests were seated at your table invited to your banquet. This is not unbecoming at a dinner but, rather, a compliment: and little honour, I hope will be detracted from you if from this dish of mine, prepared for your palate, others drink or eat, with your kindly permission.

I have almost finished my preface: one thing is left, namely my prayer: for you therefore I pray, most noble earl, that your dignity may continue to fulfill the expectation of all good men and that hope in virtue, piety, wisdom, bravery, which has truly for a long time shone in you with such brilliance, that hope may you now strive to approach so that you may achieve the glory you deserve and I may be granted the fulfillment of my prayers. May God grant that now you have begun to embrace religion, exercise piety, show virtue both at home and outside, you may progress still further and, promising still greater things for the future, you may finally receive the fruit of that religion, enjoy the reward of that piety, gain the prize of that virtue: that our most serene sovereign may deign to favour you further because of your virtue. May God protect her forever, may the good not cease to love her for her piety, may all gladly praise her for her virtue. Finally I pray, in the name of Christ our saviour who died for us, that our most kindly father, God most high and mighty may some day place upon your head the crown Christ won and conquered.

I am, now and for all time, your Honour's most devoted servant, And. Willet.

\section{Notes}

This essay emerges from a continuing project devoted to the indexing of European emblems. We wish to acknowledge here the support of the Social Sciences and Humanities Research Council of Canada.

1 The only lengthy discussion of Andrew Willet is contained in the German doctoral dissertation by Irma Tramer, Studien zu den Anfängen der puritanischen Emblemliteratur in England: WilletWhitney. diss Berlin 1934. The work is misleading in regarding Willet as a Puritan, and speculative in suggesting the extent of his knowledge of continental emblem books. The following may also be consulted: Rosemary Freeman, English Emblem Books (London: Chatto \& Windus, 1948, repr. 1968), pp. 53-5, 64-5, 234; Mario Praz, Studies in Seventeenth-Century Imagery, 2nd ed. (Rome: Edizioni di Storia e Letteratura, 1964).

2 See State Papers Domestic, James I, xciv, 79. Cit. Dictionary of National Biography (Oxford, 1959), vol. 21, p. 290.

3 See the bibliographical studies of Jesuit emblem books by G. Richard Dimler, S.J., published in Archivum Historicum Societatis Jesu 45 (1976), 129-134; 46 (1977), 377-378; 47 (1978), 240 250; 48 (1979), 297-309. Father Dimler has completed work on a bibliographic handbook of Jesuit emblem books that is to be published by Fordham University Press.

4 See Mason Tung, "Emblematic Inventions of Alciati and Whitney," English Miscellany 24 (1973), 9-17.

5 The phrase "ad aspectum depingi possunt" can be read as meaning "beautifully depicted," but that would imply the presence of illustrations, which is not the case. Since this is an unillustrated work the Latin might be rendered "beautifully described" thereby implying that the reader can form a pictorial image in his mind by reading them.

6 "Regesta," our emendation for the phrase "re gesta," derives from the verb "regero" (to bring back) and thus means a list, catalogue or record, and is not connected with "res gestae" (exploits). 
7 See the article by William S. Heckscher and Karl-August Wirth, "Emblem, Emblembuch" in the Reallexikon der deutschen Kunstgeschichte (Stuttgart, 1959), vol. 5, col. 101.

8 The cost of providing engraved illustrations is stressed by John Harington whose translation of Orlando Furioso appeared in 1591, about the time Willet's emblem book was published. See Freeman, pp. 54-5.

9 In the Held edition the picture of a shield and a grave is used in emblems XII and LXVI; Hercules appears in XVII and LI; a gourd climbing up a fir tree is used in III and CLXXXV.

10 See Margery Corbett and R.W. Lightbown, The Comely Frontispiece. The Emblematic Titlepage in England 1550-1660. (London, Henley and Boston: Routledge \& Kegan Paul, 1979).

11 Versus rapportati were frequently employed in medieval Latin verse; they are also found in the vernacular literature of 16 th and 17th centuries. One famous instance in Shakespeare is Ophelia's description of Hamlet as "The courtier's, soldier's, scholar's eye, tongue, sword" (Hamlet III,i,159). See Ernst Robert Curtius, European Literature and the Latin Middle Ages (New York: Harper \& Row, 1953), pp. 286-287; and Wolfgang Kayser, Das Sprachliche Kunstwerk (Bern and Munich: Francke Verlag, 1963), p. 130.

12 In the following discussion of Willet's emblems, we use the term "subject" to signify the theme, which is identified in general terms, and corresponds to what Henkel and Schone have termed "Bedeutung," i.e. the meaning of the emblem (see Arthur Henkel and Albrecht Schone, Emblemata. Handbuch zur Sinnbildkunst des XVI. und XVII. Jahrhunderts (Stuttgart: Metzler, 1967, 2nd ed. 1976), p. XVIII, and "Bedeutungs-Register" cols 2029-2078). This subject is often stated at least partially in the motto. We reserve the term "motif" for the identification of the pictorial, metaphoric or symbolic embodiment of the subject normally found in the picture, and often elaborated in the epigram. Willet's emblems are unillustrated; lacking pictures the motif is described in the epigram. The relationship of "motif" to "subject" approximates to what in earlier terminology has been called "vehicle" and "tenor."

13 See Peter M. Daly, Emblem Theory. Recent German Contributions to the Characterization of the Emblem Genre (Nendeln: Kraus-Thomson, 1979), pp. 52-3, 98.

14 Leaving translations aside, the first German emblem book by Mathias Holtzwart, Emblematum Tyrocinia (Strassburg: Bernhard Jobin, 1581) is a bilingual edition with texts in German and Latin.

15 Freeman, p. 64.

16 The Early English Text Society published in 1899 Queen Elizabeth's translation under the title Queen Elizabeth's Englishings of Boethius, De Consolatione Philosophiae, A.D. 1593 ..., ed. Miss Caroline Pemberton.

17 The sapphic can be perfectly reproduced in English: cf. P. Shorey's translation of Horace's Ode 2.16:

Peace the sailor prays on the wide Aegean

Tempest-tossed, when gathering wracks of storm cloud

Hide the bright moon's face, and the stars no longer

Shine on his pathway.

18 This phrase was coined by W.B. Stanford in a lecture on "The Sound of Poetry," given at McGill University in October, 1968.

19 An Apologie for Poetrie, ed. J. Churton Collins (Oxford: Clarendon Press, 1907), p. 60.

20 The unspecified work in A Choice of Emblemes and Other Devises (Leiden, 1586) by Geffrey Whitney.

21 Willet virtually borrows this phrase from Whitney who in his preface had modestly observed that most of his emblems were "gleanings out of other mens harvests" $(* * 2 v)$.

22 The Earl referred to is Robert Dudley, Earl of Leicester (1532?-1588).

23 Willet means Sir Francis Walsingham, who died April 1590. 